\title{
Author and Reader in Instructions for Use
}

\author{
Michaël F. Steehouder \\ University of Twente, The Netherlands \\ M.F.Steehouder@WMW.UTwente.NL
}

Instructions for use should not be seen as merely instrumental - they should also persuade the reader to read the text and to act accordingly. Moreover, they should establish a positive image of the product and the manufacturer. In this paper, a collection of instructions for use is used to identify strategies technical writers apply to fulfill these 'rhetorical' demands; especially strategies that involve the author-reader relationship. The analysis shows that the implied author's role is not only that of a neutral instructor, but also that of a teacher or a salesman. The reader is not only addressed as a technical 'operator', but also as a 'user' who applies the product in a 'real-life task'. The analysis also shows that technical writers sometimes use subtle politeness strategies to compensate for 'face threatening acts (FTA 's)'. However, all of these rhetorical strategies seem to be applied very unsystematically and often clumsily. The conclusion is that technical writers may be aware of rhetorical demands for their documents, but that the instrumental function still is paramount in their eyes.

\section{Introduction}

Technical documents, especially instructions for use, manuals etc., are usually characterized as being essentially instrumental. They are not designed to be attractive and persuasive, but the predominant quality criterion is usability. This traditional view on technical communication (e.g. Harris 1983; Moore 1996) was recently expressed clearly by Moore (1997, p.164):
Rhetoric is persuasive; instrumental discourse shows how to perform actions. [...] Instrumental discourse does not necessarily use reasons or appeals to logic, to the authors character, or to the audience's emotions. [...] An external set of circumstances in a user's environment usually motivates her or him to the instrumental discourse. For example [...] Rhetorical communications and salespeople may persuade customers to buy specific hardware and software, but after the sale, the customers require no persuading to read and apply the installation and operating instructions.

By contrast, however, some authors have stressed 'rhetorical' aspects of technical documents. Some years ago, the STC published a book by William Horton with the meaningful title Secrets of User-Seductive Documents - Wooing and Winning the Reluctant Reader. Horton feels that technical writers should not leave the responsibility of reading to the reader, but take the responsibility of making the reader notice, understand and act on the information. He distinguishes 'friendly' documents from 'seductive' documents. The first enable readers to do and to find; they present information clearly and are readable. Seductive documents, however, get readers to do; they show and teach, they convince and get read. 
Similar views are advocated in several other publications. Ludwig Gerisch (1995), for instance, states that operating instructions, as a part of the total product communication, have their own part in the marketing and sales strategy. They should be 'as fascinating as a thriller' - by text, design and color pictures.

Gabriele Bock (1995), after analyzing a number of German and American car manuals, found that older manuals had 'a much higher communication quality in terms of richer language, appealing illustrations, and human touch. Modern manuals tend to be abstract, uninhabited, and impersonal'. She illustrates this conclusion by discussing non-verbal elements (pictures) as well as verbal (text). Her conclusion is that:

the communication model of speaker and listener respectively writer and reader has been replaced by writer and product. Reading means no longer to understand and learn but to receive information impulses and to act appropriately. (Bock 1995, 5).

One of the important rhetorical aspects of any document is the author-reader relationship expressed in the document and perceived by the reader. Halse (1987), for instance, found that computer manuals for novices express certain author roles (friend, helper, expert, non-technical person like the reader) and certain reader characteristics (young, professional, naive, anxious to do things wrong). By paying attention to these factors, Halse states, manual writers will surely produce better manuals.

In this paper, I will explore some of the strategies applied by writers of instructions for use to establish writer-reader roles. It is not my intention to draw conclusions on the effectiveness of the various strategies, but merely to sketch the 'repertoire' writers have at their disposal and the variations that are applied in practice.

My analysis is based on a collection of 60 instructions for use of electronic consumer products. All documents were written after 1985, and all are in Dutch (originally or translated). The product categories include audiovisual equipment (television, radio, video, etc.); kitchen appliances (ovens, washing machines etc.), small household tools (mixers, electric tooth brushes etc.), do-it-yourself tools (electric drills, shredders etc.), and telecommunication equipment (telephone, fax, etc.).

\section{The persona}

Readers of documents may construct an image of the writer as an individual or as an organization comprised of people - for example an organizational identity or a corporate voice. This image does not necessarily resemble to the identity of the actual author(s) of the text, nor the image that the author intends to convey. The importance of the 'persona' created in the text - a notion that stems from literary theory - has been rather neglected in technical communication. Writers of technical documents can take use of it by creating an image that pleases the reader and accordingly motivates him/her to read the text and to act accordingly. Two aspects are especially relevant here: the identity of the persona (who is talking?) and the role this person plays.

\section{Who is talking?}

In the rhetorical situation it is useful to move away from the actual writer and to look at the person that has been put on the stage as the narrator. This is not a real person, but a 
person that is created in the text - who may be very much like the actual writer, but can also be a pure fictitious person.

The following introductory passage of a manual for a VCR shows a rather extreme, but informative illustration of the difference between the actual writer and the implied writer.

Vanharte gefeliciteerd. Met deze videorecorder (VCR) bent $\mathrm{u}$ in het bezit gekomen van een van de meest geavanceerde en makkelijk te bedienen apparaten die er op de markt zijn.

Even voorstellen: mijn naam is Philip. Ik heb tot taak $\mathrm{u}$ bij het leren kennen van uw nieuwe videorecorder behulpzaam te zijn.

Congratulations! By purchasing this video recorder (VCR) you have in your possession one of the most advanced and easy to operate

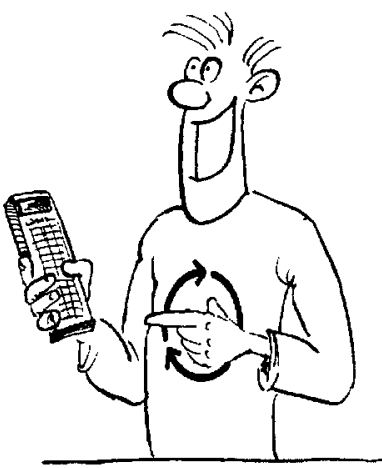
pieces of equipment that are on the market.

Let me introduce myself: my name is Philip. It is my task to assist you in getting to know your video recorder.

The manual is obviously not written by a person with the name Philip who looks like the cartoon. Philip is created in the text as an implied author.

Which kinds of implied authors appear in the corpus? The documents we collected show several options.

- The manufacturer of the product. If the pronoun we is used without further reference, the reader will assume that we refers to the manufacturer, since its name is on the cover. This occurs very frequently.

- An unidentifiable third person. If there is no first person pronoun, the reader may still assume that the implied author is the manufacturer. But instructions without first person pronouns often refer to the manufacturer as somebody else ('For more than 50 years, $X$ has been known to be a very reliable manufacturer of ....'). Therefore, I prefer to distinguish impersonal implied authors from the manufacturer.

- An identifiable third person. Sometimes the writer of the instructions is identified by name, for instance on the front page - he or she may even be introduced as an expert. Walters \& Beck (1992) notice that this option occurs mainly in so-called secondary manuals: manuals that are not published by the manufacturer but by an independent publishing company. However, such implied authors are not found in my collection.

- A fictitious person. This type of implied author occurs very seldom within the corpus. 'Philip' is the only example. Another (less clear) example I have found comes from the instructions for a car, introduced by 'your OPEL team'. 
The implied author may change within a text. Some sections may be written by 'the manufacturer', while other are written by an unidentifiable person. This occurs mainly in three situations.

- In a number of texts the introduction is written by 'the manufacturer', while the actual instructions are written by an unidentifiable third person.

- If the dominant implied author is the manufacturer, some segments that put the manufacturer in a negative perspective are written by an unidentifiable person. Disclaimers for instance: 'The manufacturer is not responsible for damage ....'.

- If the dominant implied author is an unidentifiable third person, some advice or recommendation may be written by the manufacturer. Quite suddenly and incidentally the pronoun $w e$ is used. For instance, in a manual for a video camera recorder, that is entirely written by an unidentifiable third person, we read: 'For the best recording results we recommend that you use AKAI, SONY, FUJI or MAXELL brand video tapes'. This change of persona apparently marks the contrast between the (non-obligatory) recommendation and the instructions.

\section{Roles of the persona}

In his rhetorical analysis of computer manuals for novices Halse (1986, p. 114) notes that writers try to present themselves as a friend or a trusted professional guide; they build their own ethos. Halse goes on by saying that ethos is not only built by explicit statements about the capacities or aims of the writer (or the company), but also by many more or less implicit elements of style; the most obvious of which is the way pronouns, contractions and verbs are handled. One of the decisions writers have to make for instance is whether they will use the first person pronoun or not.

Walters \& Beck (1992, p. 163) found some differences in the roles played by implied authors of software manuals. They use the profiles of 'tutor', 'teacher' or 'helper'. The writers also differ in the extent to which they distance themselves from the software, for instance by admitting certain shortcomings or difficulties with the software. If the manual is published by the software company itself, such moves are not possible, but in 'secondary documentation', it is not unusual.

Which roles do implied authors play in instructions for use? To start with: most texts are very implicit about this role. Statements like 'It is my task to assist you' are more exception than rule. Nevertheless, several roles can be distinguished. The first that can be mentioned are the roles that best fit the instrumental function of instructions - I will only discuss them in brief.

The most common role is the 'neutral instructor' who simply tells the reader what to do in certain circumstances, and what the effects will be.

A supplementary role is the 'teacher' who explains certain properties of the equipment and/or clarifies why certain actions have to be performed. These explications are usually formulated in a fashion distant to the reader, without features that could indicate persuasive intentions. A characteristic example is the following. 
Wanneer u een TV-zender vastlegt onder een nummer dat al in gebruik is, wordt de nieuwe zender vastgelegd en de oude zender gewist. Dit kan nuttig zijn als u een betere ontvangst vindt van een zender die $u$ al had vastgelegd.

If you save a TV-station on a number that is already in use, the new station will be saved and the old one will be erased. This may be useful if you discover a better channel for receiving the station than the one you saved before.

A more rhetorical role (in the sense of persuading and motivating) is the 'tutor' who guides and supervises the reading and learning behavior of the readers by encouraging them to read the document as a whole, or certain parts of it. Very common are suggestions such as: 'Read the instructions carefully before unpacking and installing the equipment' or 'Take your time to read the following safety instructions'. Sometimes, the tutor even seems to read over the reader's shoulder:

Hebt $u$ alle aanwijzingen in de hoofdstukken 'Installatie' en 'TV-zenders vastleggen' opgevolgd? Zo ja, ga dan verder met dit hoofdstuk.

Have you complied with all instructions in the chapters 'Installation' and 'programming TV channels'? If so, please continue with this chapter.

A common rhetorical role usually occurs in the beginning (introduction) of the instructions. It is the role of 'manufacturer' or 'salesman'. In this role, the implied author congratulates the user for having bought the excellent device, promises that life will be more comfortable, and the user will be happier. In addition, the implied author may state that the product is very attractive, because it is easy to handle, advanced in its technology and/or manufactured by a company that has a long reputation of good craftsmanship. Etcetera..

This role, which meets the idea of the instructions as extension of the marketing communication (cf. Gerisch 1995), is usually worked out very unpretentiously and soberly. In many cases, it comprises no more than an obligatory opening sentence.

Gefeliciteerd met Uw nieuwe magnetron.

Congratulations with you new microwave oven.

Such sentences often take a form that discloses the implied author's distance to, or lack of identification with the content. The pronoun we only occurs infrequently. Instead the passive is used as a means of expressing non-identification (cf. Cornelis 1997), or verbs are nominalized. In the following example, the name of the manufacturer is even left out, although his experience and craftsmanship are mentioned.

SKIL machines worden ontwikkeld en geproduceerd op basis van een meer dan 60-jarige ervaring en volgens de hoogste technologische normen van vandaag.

SKIL equipment are designed and manufactured on the basis of more than 60 years of experience and according to the highest technological standards of today. 
If more than a small trace of marketing purposes can be found, it usually takes the form of an enumeration of features of the equipment. In most cases this enumeration seems incoherent, and stereotypical. Almost all products are easy to use (even if a 72-page manual turns out to be needed!), contain advanced technological features, meet high quality standards and will offer you more pleasure and comfort in life.

Another rhetorical role is the 'advisor'. In addition to the instructions that are needed to operate the equipment correctly, sometimes useful advice is given to enable the user to get more out of the equipment. As stated earlier, such advice is often given with the pronoun we, even if it is not used at any other place in the text. For instance, in the instructions of the Miele dishwasher, the only segment where the unidentifiable implied author makes place for the manufacturer is the following:

Wij adviseren om

- bijzonder waardevol glaswerk met de hand te blijven afwassen

- bij aanschaf van nieuw serviesgoed of bestek de geschiktheid voor de afwasmachine eerst te laten bevestigen.

We recommend:

- very valuable glassware be washed by hand

- verify whether new tableware or cutlery is suitable for dishwashers before making a purchase.

However, usually the implied author keeps distance from the advice, for instance by avoiding direct forms (e.g. imperatives) or by using nominalizations. As a matter of fact, the pronoun we is only used in a minority of the examples. The following is a very common recommendation in the passive, which expresses a degree of non-identification which does not seem to fit the notion of useful advice.

Het gebruik van cassettes die langer zijn dan 90 minuten wordt niet aangeraden.

The use of cassettes longer than 90 minutes is not recommended.

From the examples cited here, we come to the conclusion that, although the implied authors may play 'rhetorical' roles like a salesman or advisor, these roles are played with much distance to the reader by using syntactical forms that suggest non-involvement rather than conviction and persuasiveness.

\section{The implied reader}

Just as we should distinguish the actual writer from the implied author or persona, it is useful to distinguish the actual reader of a document from the implied reader, who is also referred to as 'mock reader', 'inside reader', 'authorial reader', 'created reader', 'fictitious reader' or even 'virtual reader' (cf. Goodwin 1991). The writer creates a reader in the text by assuming certain reader characteristics - for instance certain prior knowledge, opinions, desires, preferences, etcetera. The actual reader is invited to 'play the role' of the implied reader, and thus to understand, react and believe as the implied reader does. As long as the actual reader is able and willing to play this role, the communication can be expected to be successful. 
The following example illustrates this.

De magnetron

Neemt $u$ meteen maar eens een proef op de som. Warm bijvoorbeeld de koffie van vanmorgen eens op: hij smaakt alsof hij vers is gezet.

1. Neem een kopje zonder gouden of zilveren decor en zet er een lepeltje in. Schuif het rooster op richel 1 in de oven. Zet het kopje in het midden op het rooster.

2. Vermogen MAX indrukken.

3. Met de instelknop 1 minuut instellen.

4. Starttoets indrukken.

5. Na een minuut hoort $\mathrm{u}$ een signaal dat $\mathrm{u}$ met de wistoets voortijdig kunt uitschakelen.

6. De koffie is warm.

7. Naast dit voorbeeld vindt $u$ in de tabellen nog vele andere voorbeelden.

The microwave oven

Just start testing it out. For instance by heating up this morning's coffee: it will taste as if it is freshly made.

1. Take a cup without gold or silver decorations and put a teaspoon in it. Push the grid into the oven on ridge 1. Put the cup in the center of the grid.

2. Set power to MAX.

3. Select 1 minute with dial 1.

4. Push the Start button.

5. After one minute you will hear the signal that you can turn it off with the Erase button.

6. The coffee is warm.

7. In addition to this example you will find many other examples in the tables.

It is unlikely the writer assumed that all real readers have a cup of cold coffee left from this morning's breakfast, or that they want a cup of (warm) coffee exactly at the moment of reading. Instead, the text (or the writer) creates an implied reader, and the actual reader is supposed to 'play the role' or to identify with this fictitious person. And since it is not very hard nor unpleasant to imagine that you want a coffee and you have some cold coffee left from this morning, we may assume that no serious problems will occur in this case.

Which reader roles can be found in instructions for use? Of course, the most obvious is that of the operator of the device: the person who tries to make it work. In certain parts of the instructions, however, the implied reader may also be:

- A customer who should be satisfied with the product (the counterpart of the implied author / salesman).

- A mechanic who has to assemble the equipment and/or diagnose and solve problems.

- A (potential) complainer against whom certain legal restrictions are made.

In the following section I will confine myself to two roles closely associated with the more rhetorical aspects of the instructions, namely the reader as 'user' and the reader as 'reader'. 


\section{The reader: operator or user}

If we ask people what they do with their CD-player, they will not answer 'I press the ON/OFF button' nor 'I adjust the Volume'. Rather they 'play Italian opera arias' or other favorites. In other words: owners of such equipment do not identify themselves as operators of the equipment but music amateurs, who use the equipment. Shneiderman (1987, p. 47-52) in his work on user interfaces, makes a very useful distinction between three levels of knowledge that software users need. This distinction may be expanded to users of other technical devices. The distinction is between:

- Syntactic knowledge: knowing which commands, buttons etc. have to be used to produce a certain effect.

- Semantic knowledge of software and hardware concepts: knowing the parts of it, and the functions, what they do, which restrictions they have, etc.

- Semantic knowledge of task concepts: knowledge of the 'real world task' the software is meant to support.

As an example Shneiderman refers to the task of writing a business letter with a computer. The user must know how to write a letter, how choose content and style, and how to apply conventions. These are all real-life task concepts. They hold not only for users of text processing programs, but also for those who use pen-and-paper, a typing machine or a dictating machine. In addition, users of text processing software must understand computer functions such as storing a file on a disk and printing it (semantic knowledge of computer concepts), and he must know the details of the Save command (syntactical knowledge).

Instructions of use generally refer to the syntactic and semantic aspects of the equipment, appealing to a reader who is primarily an operator of the equipment. However, sometimes they also refer to the real-life task the reader carries out with the equipment; then the text appeals to the reader in the role of 'a normal human being, performing some task': the user.

The instructions for the microwave oven above gave an example of the latter: they not only referred to the buttons, but also to the practical task of warming up some coffee. The corpus I investigated shows a number of fragments where this shift from equipment to real life was made. The distinction is not always very sharp, as the following example from an instruction for a steam iron illustrates:

- Als het textiel een bepaalde 'finish' heeft gekregen (glans, kreuk, structuur, reliëf), dan kunt $u$ beter op een wat lagere temperatuur strijken.

- Het strijkijzer warmt snel op, maar koelt langzamer af. Daarom kunt $\mathbf{u}$ het beste beginnen met de synthetische stoffen (kunststoffen), die op de laagste temperatuur gestreken moeten worden.

- Fluweel en andere weefsels die snel glimplekken vertonen, strijkt $\mathrm{u}$ altijd in één richting (met de vleug mee) en zonder drukken. Zorg dat het strijkijzer steeds in beweging blijft. 
- If the textile has a certain 'finish' (glow, crease, structure, relief), you better iron on a bit lower temperature.

- The iron heats up fast, but it cools slowly. Therefore it is better to begin with the synthetic textile (artificial textile), that have to be ironed at the lowest temperature.

- You should always iron velvet and other materials that get shiny spots easily in one direction (following the nap) and without applying pressure. Keep the iron moving continuously.

Although the second recommendation is still closely linked to the steam iron in question (the device), the other two have to do with the task of ironing in general - they apply to other irons too. I found similar instructions for real-life tasks in other documents. For instance, almost all instructions for microwave ovens include ready-made recipes for all kinds of dishes; instructions for a electric shaver included tips for using pre and after shave lotion; instructions for a deep fryer advises to coat fish, meat and some vegetables with breadcrumbs before deep-frying them; instructions for a central heating thermostat advises users to program a night temperature between 10 and $14{ }^{\circ} \mathrm{C}$. All these examples refer to topics relevant to the real-life task rather than to the syntax or semantics of the device.

It should be noted, however, that not all instructions that go beyond the device are 'real life task' instructions. For instance, warnings may be supported by general information, or may be of a very generic nature ('electric equipment should be guarded against water'). They do not, as real-life task instructions do, refer to the task the technical equipment is used for. But there are many borderline cases.

What factors determine the presence of real-life task instructions? Since my collection of documents is not representative, it is not possible to put forward solid claims. However, some factors seem to be of relevance.

First, it seems that 'real life' instructions occur more often in instructions for relatively new technologies. The microwave oven is an example. This fact is also signaled by Mårdsjö (1992), who gives the example of an early telephone manual which showed how the receiver should be held in order to listen and speak easily (with the recommendation to hold it in you left hand, leaving the right hand free for making notes).

However, this explanation does not completely hold. My corpus includes a number of instructions for relatively new equipment, such as fax machines, video cameras, and wireless telephones, with no or only incidental references to real-life tasks. On the other hand, many instructions for widely accepted devices, such as irons, washing machines and blenders show instructions on a real-life level.

A number of cases where real-life instructions occur may be explained by the fact that real-life conditions are directly relevant to the operations to be performed. For instance, when it comes to programming the warming up times for deep frozen food in a microwave oven, the weight and other characteristics are relevant. Adding a timetable for a list of concrete common food products seems natural. However, in some comparable cases, the conditions are given in a much more abstract, technical manner (for instance with amplifiers by referring to 'low frequencies' instead of 'low tones'). 
It can tentatively be concluded that real life plays a more important role if the product is a more traditional and less technologically advanced household appliance (the 'white' equipment) than if it is a more modern and technologically sophisticated appliance (the 'black' equipment). Instructions for audio-visual equipment, communication equipment and do-it-yourself tools contain relatively little real-life instructions, while those for ovens, washing machines and small household equipment contain relatively many. However, exceptions are too manifold to regard this as a straight mechanism. I already mentioned the advice for pre and after shave lotion in instructions for an electric shaver; and I found advice for sandpaper woodwork in instructions for a sanding machine.

Nevertheless, there seems to be a tendency to create different implied readers: 'users' for 'white' equipment, and 'operators' for 'black' equipment.

\section{The reader as reader}

Almost all instructions for use contain some kind of reading advice. It may vary from a simple encouragement to read the text, to complete arguments persuading the reader to do so. In addition, I found several instructions that make clear who should read a certain section or skip it.

Of course, it is very important that consumers read instructions for use, but writers seem to be aware that they tend not to. So they urge the reader to read by using an argument.

There prove to be two sorts of arguments: threats and rewards. An example of the first is the following - the argument that not-reading will lead to damage or accidents:

Lees voor het eerste gebruik van uw sledestofzuiger deze gebruiksaanwijzing zorgvuldig door om schade en/of ongevallen door ondeskundig gebruik te voorkomen.

Before the first use of your sled vacuum cleaner, read these instructions carefully to avoid damage of accidents through improper use.

Another way of threatening the reader is to include not-reading of the instructions in the disclaimer:

De fabrikant kan niet aansprakelijk worden gesteld voor schade die ontstaat doordat de garantievoorwaarden, de veiligheidsvoorschriften of de voorzorgsmaatregelen niet in acht worden genomen.

The manufacturer is not legally liable for damage caused by neglecting the warranty conditions, the safety instructions, or the precautions.

Notice that the formulation also creates a distance from the (implied) reader by using nominalizations rather than direct addresses ('if you use the vacuum cleaner incompetently, or neglect the warranty conditions ... etc.). This can be seen as a form of politeness, which I will discuss later.

Naturally, threats are by definition unfriendly. So it is logical that the opposite argument for reading is used much more frequently: the reward. Reading the instructions is rewarded by higher performance of the equipment and better results for the user. 
Het verheugt ons dat $u$ uit onze serie een kleurentelevisie heeft aangeschaft. Het is een zeer modern toestel met vele mogelijkheden, die $u$ het beste leert kennen als $u$ de gebruiksaanwijzing zorgvuldig doorleest.

We are pleased that you purchased a color television set from our series. It is a very modern set with many features which are best learned by reading the instructions for use carefully.

In some instructions the arguments for reading are a bit surprising - sometimes it is even difficult to take them serious, as is shown in the following example:

Maak gebruik van deze handleiding:

- $\mathrm{U}$ vind er de nodige informatie in.

- U kunt zich op het trefwoordenregister oriënteren.

- U leert de technische verfijningen kennen.

- U zult meer vreugde aan uw Astra beleven.

- U beheerst uw auto volledig.

De handleiding hoort in de auto: klaar voor het grijpen in het handschoenenkastje.

Make use of these instructions

- You will find the necessary information in it

- You can orientate yourself via the subject index

- U will learn to know the technical refinements

- You will enjoy your Astra more

- You will fully control your car.

The instructions belong in the glove compartment: ready for use.

Although it seems a sensible strategy to avoid (or minimize) threats and to use rewards as arguments for reading the manual, the paramount impression of these examples which are typical for the corpus - is a poor one. Writers do not succeed in finding convincing positive arguments for reading; the threats seem much more convincing despite the fact that they sound less friendly.

Apart from this one can question the use of trying to get users to read instructions by giving them (textual) arguments. It seems that indirect arguments (good and easy looking instructions) are much more effective.

\section{Politeness}

In their classic book on politeness, Brown \& Levinson (1987) discuss the fact that many communicative acts threaten the 'face' of the addressee(s); they are called Face Threatening Acts (FTA's). There are two types of FTA's. A communicative act is a negative FTA if the addressee's freedom of acting is restricted. Examples are: order, ask favors, showing interest in somebody's possessions (suggesting that you want to have them), or giving something (which puts an obligation on the addressee to be thankful or to pay something back). Positive FTA's damage the addressee's good image or feeling of honor. Examples are: criticism, accusation.

In normal communication, FTA's are almost inevitable, since language users want others to do something, and want to express (or imply) certain judgments about others. But whenever language users have to perform FTA's, they will also try to minimize the threat, since it generally will be to everyone's interest to maintain face. Brown \& 
Levinson identified a large number of face saving politeness strategies which they claim to be universal, i.e. used in all languages and all cultures.

An instructional text is essentially 'by definition' a negative FTA - after all it restricts the reader's freedom by prescribing actions. Nevertheless, under normal circumstances instructions are not felt as FTA's. Writers use explicit language forms such as imperatives without redressing, and readers do not feel threatened by that. Brown \& Levinson explain this by stating that instructions are (1) task-oriented and (2) primarily in the addressee's interest (p. 97-98). One could add that instructions do not place an obligation on the reader. The reader is free to neglect them; the (implied!) author is indifferent. So, instructions for use are not face threatening acts, and do not urge the writer to use politeness strategies. To put it in Moore's (1997) terminology: they do not threaten the readers face because they are instrumental.

When, however, the (implied) author goes beyond this 'instrumental neutralism', it is possible that instructions become FTA's. Since every human being normally seeks to avoid damaging the face of others (Brown \& Levinson), it can be expected that the author then tries to compensate for the FTA by using politeness strategies.

Interesting examples of FTA's in Instructions for Use are sentences that refer to an erroneous action by the user of the equipment, leading to the malfunctioning of the equipment. For instance, an instruction for a dishwasher contains the following warning:

If you fill the salt reservoir with a cleaning agent, this will cause irreversible damage to the water softener!

The assumption that the user could be so stupid as to fill the salt reservoir with a cleaning agent, can be felt as a positive FTA: it affects the user's self-esteem. That explains why the actual text of the instruction was slightly different:

Indien u per abuis het zoutreservoir met reinigingsmiddel vult, dan leidt dit onherroepelijk tot beschadiging van de waterontharder!

If you fill the salt reservoir with a cleaning agent by mistake, this will cause irreversible damage to the water softener!

Adding a qualifier like 'by mistake' is a politeness strategy that compensates for the FTA. Another politeness strategy is obscuring the responsible actor (the user/reader) by using the passive voice.

Attentie! Het kunststofhuis van de wateraansluiting bevat een electrisch onderdeel. Het mag derhalve niet in vloeistoffen ondergedompeld worden.

Caution! The synthetic cover of the water connection contains an electrical unit. Therefore it should not be immersed in water!

And in the next example, the FTA is redressed by using a nominalization. Instead of 'If you use a bad quality cassette', the text reads: 
Bij gehuurde cassettes van slechte kwaliteit kunnen horizontale ruisbanden door het stilstaand beeld lopen.

With bad quality rented cassettes, horizontal interference can run through the stationary picture.

(The bad cassette does not even belong to the reader!).

\section{Conclusions}

My analysis of instructions of use has shed some light on the ways technical writers create a persona and an implied reader in their documents. By looking at the identities and the roles of the persona and the roles of the readers some 'rhetorical' aspects of instructions can be understood.

I started this paper by citing several authors who argue that instructive documents should not be regarded as purely instrumental - they should also have a 'rhetorical' function, in that they have to persuade the user to read and follow the instructions, to establish a positive image of the product and the manufacturer, and, more ethically: to become more 'human'. If we look at the results of the analysis, we may conclude that technical writers seem to be aware of this rhetorical aspect: the consumers are complimented with their choice of the product, the readers are encouraged to read the instructions, and sometimes the reader is addressed as a 'user' rather than an 'operator' of the product. If necessary, politeness strategies are used to compensate for possible face threatening acts.

But at the same time, technical writers seem to be uncomfortable with these noninstrumental side of their writing task. The strategies identified in this paper, are usually applied unsystematically, and sometimes quite clumsily. Only seldom instructions give the impression that the writer has carefully considered how he would appeal to the reader.

Would a strongly rhetorical approach really be effective? Would it really lead to a higher willingness to read the instructions and to act as required, and would they really produce a better image of product and manufacturer? Text analysis is not a research method which can answer such questions - to do so we need experimental research. But I think that would be premature at the moment. It seems more urgent to me to identify in more detail the spectrum of rhetorical strategies writers of instructions can apply.

\section{Acknowledgments}

I am grateful to Carel Jansen, Fons Maes, Peter Jan Schellens and Scott DeLoach for their useful comments on an earlier draft of this paper. Steven Ralston corrected my English. Angelique Boekelder collected and arranged much of the collection of instructions I used for this study.

\section{References}

Bock, Gabriele. "The disappearance of communication culture in technical documents," In: M.F. Steehouder (Ed.), Disappearing borders. Preseedings Forum 95 international conference for technical communicators, Stuttgart: Intecom, 1995. 
Brown, Penelope, \& Levinson, Stephen C. Politeness: Some universals in language usage. Cambridge MS: Cambridge University Press, 1987.

Cornelis, Louise H. Passive and perspective. Utrecht studies in language and communication Vol. 10. Amsterdam / Atlanta GA: Rodopi, 1997.

Gerisch, Ludwig. "Towards self-advertising operating instructions," In: M.F. Steehouder (Ed.), Disappearing borders. Preseedings Forum 95 international conference for technical communicators. Stuttgart: Intecom, 1995.

Goodwin, David. "Emplotting the reader: motivation and technical documentation," Journal of technical writing and communication 21:2 (1991), 99-115.

Halse, Ronald. "Computer manuals for novices: the rhetorical situation," Journal of technical writing and communication 16:1/2 (1986), 105-120.

Harris, Elizabeth. "A theoretical perspective on 'how to' discourse," In: P.V. Anderson, R.J. Brockmann \& C.R. Miller (Eds.). New essays in technical and scientific communication: research, theory, practice. Farmingdale NY: Baywood, 1983, 139156.

Horton, William. Secrets of user-seductive documents. Arlington VA: Society for Technical Documentation (no date).

Mårdsjö, Karin. "Man - text - technology: Technical manuals as a means of communication". In: M.F. Steehouder et. al. (Eds), Quality of technical communication, Amsterdam/Atlanta GA: Rodopi, 1992, 185-200.

Moore, Patrick. Rhetorical vs. instrumental approaches to teaching technical communication. Technical communication 41:2 (1997), 163-173.

Shneiderman, Ben. Designing the user interface: Strategies for effective humancomputer interaction. Reading, MA [etc.] : Addison-Wesley, 1987.

Walters, Nancy J. \& Beck, Charles E. "A discourse analysis of software documentation: Implications for the profession", IEEE transactions on professional communication, 35:3 (1992), 156-167. 